\title{
Gastrointestinal Stromal Tumor cM0 TNM Finding v8
}

National Cancer Institute

\section{Source}

National Cancer Institute. Gastrointestinal Stromal Tumor cMO TNM Finding v8. NCI

Thesaurus. Code C136752.

Gastrointestinal stromal tumor without distant metastasis. (from AJCC 8th Ed.) 